FRANZ VON BENDA-BECKMANN

\title{
Contestations over a life-giving force Water rights and conflicts, with special reference to Indonesia
}

\section{Introduction}

Water is a life-giving force. It is vital as drinking water, for growing food, for a healthy environment, and for energy and industrial production. Water is essential for life. To deny people water is to sentence them to certain death. And there is no substitute for water. As an essential requirement for life, it is similar to air. But unlike air, it is far more restricted in space and time. This makes it a unique resource. Because of its importance, water, especially under conditions of scarcity, becomes the subject of legal regulations under which the appropriation, use, and control of water are structured and legitimated. In most contemporary post-colonial states, various legal regulations, based on and legitimated by state legislation, coexist with religious laws or traditional local laws, a condition frequently summarized as 'legal pluralism' (Griffiths 1986; F. von Benda-Beckmann 1997). Since water courses often cross national borders, regulations are also included in international law and treaties. Given its life-giving force, it has recently even been suggested that a collective right to water should be brought under human rights mechanisms. ${ }^{1}$ For the same reason, water and rights to water are often contested and trigger conflicts. Some of these conflicts are temporary, merely concerned with having sufficient water for irrigating a rice field at the right time; once the situation has passed, it is too late to change things. Other conflicts are seasonal, as are many water needs, and subside when water no longer is needed. But many conflicts are structural, and concern the distribution of water in both the present and the future. Since law, and rights to water defined in law, are a crucial legitimation of claims to water, water rights are an important resource in economic and political struggles over water. Under conditions of legal pluralism,

1 The human right to water is generally derived from the human right to life, including food, drinking water, health, clean environment (see, for example, McCaffrey 1997; see also Baehr and Van der Wal 1990). It remains disputed whether such a right would be considered an individual or a collective human right, see Donnelly 1990 and Burgers 1990. 
conflicts over water are often played out as conflicts between different legal orders, between the law of the state and local (traditional, customary) legal forms. ${ }^{2}$

In this article I discuss some of the characteristic properties of water rights and of conflicts over water and over water rights. I start with a little story about a water conflict in West Sumatra. This story is used later to illustrate some of the complexities of conflicts over water and water rights, in Indonesia and elsewhere.

\section{The spring of Sungai Tenang}

In the middle of the nineteenth century, Fort de Kock became the most important military and administrative post of the Dutch East Indies colonial government in the recently conquered Padang highlands in Minangkabau, West Sumatra. The increasing demand for clean drinking water for Dutch civil servants and for the soldiers stationed at Fort de Kock was satisfied by constructing pipelines from the village of Sungai Tenang located on the slopes of Gunung Singgalang, one of the three volcanoes dominating the Padang highlands. Before 1875, the water had mainly been used in Sungai Tenang but had also been shared with the other villages in laras Banuampu, a federation of villages, but not with the people of Kurai, the neighbouring laras where Fort de Kock was. The Dutch request to construct pipelines to Fort de Kock had met with resistance. A local adat leader wanted to use the water for expanding the area of wet-rice cultivation. After the Dutch had suppressed the local protest - the adat leader was allegedly poisoned - the pipelines were built. But it was not until 1906 that the water connection really started. After Indonesia's independence, the city, now named Bukit Tinggi, grew and its demand for water increased. New pipelines were constructed. Now, there are altogether six pipelines. A regional parastatal company, a PDAM, Perusahan Daerah Air Minum, in Bukit Tinggi manages the distribution of the water.

The people of Sungai Tenang never received any compensation for their water. They had complained about this for a long time. For them, the water was and always had been part of their ulayat, their village territory. According to Minangkabau (adat) law these resources were under the control of the village government. Outsiders could get access and use rights to ulayat resources, but had to acknowledge the right of the village and had to give a share of the profits to the holders of the right, in colonial times usually $10 \%$. But it was not easy to enforce these claims. Especially under the Suharto regime, the rural population had learnt, often the hard way, that openly questioning or even contradicting the government's interpretation of the legal order was a dangerous affair. And the government regarded these resources as state resources 2 See Boelens and Dávila 1998; Bruns and Meinzen-Dick 2000; R. Pradhan , F. von Benda-Beckmann and K. von Benda-Beckmann 2000. 
under the constitution and the Basic Agrarian Law of $1960 .^{3}$ So whatever the people of Sungai Tenang and the surrounding villages thought of the exploitation of their water by the drinking water company, they kept quiet about it.

This changed after the fall of the Suharto regime in 1998. The new orde reformasi had led to more political freedom. Moreover, the government was planning a policy of decentralization, which in West Sumatra was to lead to a renewed strengthening of adat-based forms of village organization and resource rights (see F. and K. von Benda-Beckmann 2001a,b). In this new spirit, the people of Sungai Tenang in 1998 started to discuss how they could assert their rights over water and get a share of the PDAM profits. They tried to enter negotiations with the PDAM and the mayor of Bukit Tinggi. The latter refused. So in 2000 they decided to cut off the water. This had been decided in a series of mass meetings in which young and old had participated, and in which some prominent sons of the village, among them a doctor and lecturer at the university, had taken an active role. They had carefully prepared the move for some time, announcing several times in the local newspaper that they would cut off the water supply if their demands were not met. When the water was indeed cut off, the police came to Sungai Tenang. But there was a demonstration going on. About 1,500 young men, from all over Banuampu, prevented the police from entering the village. When the PDAM realized that the mobilization of these state forces would not succeed, it was ready to negotiate. The eventual outcome was that Sungai Tenang would receive $6 \%$ of the PDAM's profits from water sales. This was accepted and one payment has already been made. Discussions continue over a further one percent, which had been agreed upon in principle, but it was unclear whether it would be paid by the city or the PDAM. These payments were still being made when my wife and I visited Sungai Tenang in early 2005. This little story tells a lot about the nature of water rights and of conflicts over water.

\section{Legal and political pluralism}

Let me start with the obvious. The conflict over water in Sungai Tenang is a classical case of legal pluralism in action. The people of Sungai Tenang challenged the rights held by the state, and the rights derived from concessions or licenses given by the government to the PDAM. They mobilized adat, or adat law, as an alternative source of legitimacy for claims over water. And they mobilized local manpower to enforce this claim. In West Sumatra, and in Indonesia in general, such a case is not an isolated one; they have become quite frequent in recent times, although their outcome varies. ${ }^{4}$ For instance,

3 Like most post-colonial states, the Republic of Indonesia had more or less taken over the rights to so-called wastelands (woeste gronden) under the Domain Declaration of 1870. See F. von Benda-Beckmann 1979; Hardiyanto 1997; Fitzpatrick 1999.

4 F. and. K. von Benda-Beckmann 2001a,b; Li 2000; Acciaioli 2001. 
not far from Sungai Tenang, between Gunung Singgalang and the coast, lies Lake Maninjau, a big crater lake. At the flow-out point, there is a hydroelectric plant of the State Electricity Company PLN (Perusahan Listrik Negara). Here also, villages have started to claim a share in the profit of the electricity company, basing their claims on village rights to the lake as their ulayat. Similar negotiations are taking place between the PLN and the villages bordering Lake Singkarak, where another hydroelectric plant is located. This struggle has not yet been concluded. Similar contests, sometimes taking the form of violent conflict, sometimes of negotiations or court proceedings, also occur with respect to land, forest areas, and plantations, and the land on which the cement factory close to Padang is located and the resources used by it (see F. and K. von Benda-Beckmann 2001b; Sakai 2003). The West Sumatran newspapers are full of reports of such incidents.

\section{Multifunctionality, scarcity and conflict}

The Sungai Tenang case also points to the multifunctionality of water. Water can be used for many different things. While the Sungai Tenang village wanted to use the water for expanding the irrigated area, the city wanted it as drinking water. Here, only two different uses or functions came into conflict. But the range of uses of water is much wider. ${ }^{5}$ It can be used as drinking water, as a means of subsistence or for commercial agriculture, for generating energy through hydropower, as a strategic resource for military purposes, for transportation, for trade, and last (and often least) as 'nature'. Lakesides can be used for fishing and tourist development (see Simbolon 1998). Moreover, water can be, and often is, a political resource, a 'strategic political commodity' (Derman 1998:75). Granting or withholding access to water can be used for creating or maintaining political dependence. Many conflicts, like the one in Sungai Tenang, are not only about the rights to water as such, but mainly about which use a given water resource should have.

The multifunctionality of water is also related to scarcity. Water scarcity is relative. Indonesia, like most areas of Southeast Asia, is blessed in most of its regions with abundant fresh water. In terms of absolute numbers, the availability of water still easily meets present needs. But such averages do not tell us much, because the actual accessibility and distribution of water is always mediated by hydro-geographical and climatic conditions as well as popula-

5 See F. von Benda-Beckmann, K. von Benda-Beckmann and Spiertz 1997. Falkenmark (1997:26) distinguishes four major functions, a health function, a habitat function, a carrier function, and a production function. Concerning the production function, he distinguishes 1. biomass production, operated by a flow of 'green' water, entering though the roots and leaving through the foliage; and 2. societal production in households and industry, based on "blue" water, withdrawn while passing through the landscape and delivered to cities and industries through water supply systems, 
tion density. ${ }^{6}$ Within hydro-ecological regions, political, economic and social organization lead to differential possibilities to access and use water, varying with rank, class, age and gender (Johnston and Donahue 1998:2). And even where water is not scarce in terms of hydrological availability, it can be made scarce because of political organization and decisions.

But overexploitation of water through new extraction technologies, the intensification of agriculture, and new consumptive demands of an evergrowing population and consumption standards have led to severe scarcity. Under conditions of (absolute and relative) scarcity, conflicts over water with the same function, for instance irrigation, tend to increase. The intensification of irrigated agriculture has decreased the availability of water for downstream users of irrigation water. In 1999, upon returning to Candung Kota Lawas, the West Sumatran village where my wife and I did research in the mid-1970s, we observed such a change. The house we had lived in then had been right in the middle of wet-rice fields, with one regular and another occasional rice season. In recent years, there has not been sufficient water for even one rice harvest. In the major cities, the distribution of drinking water is dramatically uneven between the richer inhabitants, business areas and hotels, and the poorer people living in kampung or squatter settlements. There are similar problems in the coastal and pelagic waters with which Indonesia is blessed, which are the habitat of important marine resources. But fishing efforts have increased, stocks decreased, and local artisanal fishers have to compete with commercial and industrial fishing enterprises, national and foreign, legal and illegal. Moreover, water is increasingly polluted (see Osseweijer, this volume; Pannell and F. von Benda-Beckmann 1998). Conflicts over the functions of water have also increased. In West Sumatra, for instance, hydropower projects compete with irrigation needs. The level of the two lakes Singkarak and Maninjau has gone down dramatically, at the same time affecting water supply for irrigation, fishing, and the production of electricity at the same time. Such conflicts are also common in other parts of Indonesia and Asia. ${ }^{7}$

So, even in water-rich Indonesia, water scarcity (or relative scarcity) increasingly leads to conflicts in the context of an ever more complex constellation of actors interested in controlling and using water. Conflicts need not be only between local political organizations and their law and the state and state regulation, or between public organizations and private economic interests. Clashes can also occur within the state apparatus. Given the multifunctional uses of water, public works, irrigation departments, the ministry of agriculture, of forestry, of fisheries, or tourism and the environment, may

6 See Saeijs and Van Berkel 1997 and Falkenmark 1997 on the scarcity of fresh water on a global scale. See also Postel 1992; Gleick 1993; Johnston and Donahue 1998.

7 See Syed Zahir Sadeque 2000 on rural Bangladesh; see Kurnia, Avianto and Bruns 2000 for West Java, Wiber 1991 for the Philippines. 
have very different ideas about the uses of water (see Simbolon 1998 on Lake Toba). Moreover, political and economic interests at the central level and at the regional level of the state organization may vary considerably and lead to conflict. This plays an increasingly important role in the current process of decentralization, where there is a tug of war between the political centre, which does not want to lose control over natural resources, and the districts and villages, which argue that this control should be decentralized.

\section{Water rights}

This leads to a closer examination of the complexities of water rights stemming from the physical properties of water, its fluidity, and its multifunctional potential. Because of its fluidity, the same source of water is generally used by more than one user. The multifunctionality and the fluidity of the resource require that rights be defined relationally, in relation to other rights, uses in relation to other uses and in relation to other users (see Hammoudi 1984; F. and K. von Benda-Beckmann 2000; Roth, Boelens and Zwarteveen 2005). And because of its fluidity, water rights cannot be 'fixed' in time and space as easily as, for instance, rights to land. Moreover, water is always on, under, or adjacent to land. It is frequently captured and stored in artificial structures, material artefacts such as ponds, tanks, wells, or behind dams, and is transported and delivered through pipelines or canals. This raises the question how the different aspects of legitimate control and use of water in relation to land and to material artefacts are expressed and allocated. Generally speaking, water rights rarely isolate water as an object of rights as distinct from rights to the land or the physical structures through which it flows (F. von Benda-Beckmann et al. 1997:224). In the case of springs, groundwater, and water in wells, rights to water are usually directly linked to rights to the surrounding land. ${ }^{8}$ This is also quite typical for adat systems in Indonesia. ${ }^{9}$ Land and water are seen as more or less one object of property rights, although the exclusive character of water rights is often softened by relational legal, moral and religious principles that oblige holders of water rights to use only as much as they need and to share with those in real need. The geographical scope of such relations, however, is usually bounded. This is less a matter of hydrological boundaries than of socio-political ones. In the Sungai Tenang case, for instance, the water on the ulayat of Sungai Tenang was also shared with the other villages of their laras Banuampu, but not with neighbouring Kurai.

8 Such land may be private land, the land of descent groups, clans or villages, see Ambler 1989.

9 This is government law in most states that have been influenced by English common law. See Ambler 1989; Willinck 1909 for Minangkabau; see the Pandecten van het Adatrecht 1914, see Van Vollenhoven's (1918) descriptions of adat laws in Indonesia. 
With regard to flowing water, many legal systems, including traditional laws, usually recognize so-called riparian rights, rights of landowners to take water from the water courses bordering their lands. When water courses have been altered and improved through artificial physical structures, for instance the construction of an irrigation system, the labour investment is seen as creating rights to the water. For Minangkabau, Ambler (1989) has given a detailed description of Minangkabau adat concerning irrigation systems, dealing with the headworks, distribution weirs, and canals. The general principle is that those who have built a headwork of an irrigation system are the owners of that physical structure. This is the Lockean idea of the emergence and legitimation of private rights out of what is common to all. Those who have first used water in this way have prior rights; newcomers to the system will have to negotiate access to water. It is, however, not so much the actual labour which counts, but the control over labour. Many irrigation systems that are romantically labelled 'farmer built and managed' were created by landlords with the labour of slaves or bonded labourers (see R. Pradhan et al. 2000). But it is not only labour; capital investment is also important. This becomes more important the more sophisticated and costly the water delivery technology is. Control over technology and capital thus can become more important that the actual labour input, and often leads to conditions whereby those who control and command technology and capital also command labour and acquire priority rights to water. These ideas probably also colour the attitude of donor agencies towards the irrigation systems they help to create or rehabilitate. The money invested (although it may simply be donor money and thus actually raise the debt of the receiving country) gives a sense of ownership and the right to dictate how control and use rights to water should be distributed.

The advances of water-related technology have led to new types of conflict and raised new legal problems. One dramatic development has been the advance in the construction of large dams, leading to the displacement of large populations and dramatic changes in the environment, greatly changing the agro-ecological landscape and the economic life chances of the population depending on water. This has led to local, national and world-wide protests. In Indonesia, perhaps the most well-known case is Kedungombo, where the construction of a large dam required the use of approximately 6,127 hectares of land inhabited by about 60,000 families. ${ }^{10}$ Another major development has been the technological advance in borehole drilling. This has affected underground water tables significantly, often over quite considerable geographical distances. ${ }^{11}$ Through the legal fusion of ownership rights to pieces of the

10 See Aditjondro 1998; Fitzpatrick 1999. See Simbolon 1998 on the Asahan project in North Sumatra. See also Editorial 1999; Shiva 1999.

11 Even in states like Bangladesh, which historically have suffered from floods and water abundance, the increased capacity of pumps and the increasing extraction of groundwater has led to shallow water tables and to water scarcity (Syed Zahir Sadeque 2000: 275 ff.). 
earth's surface and to the water below it, or at least the water collected in tube or bore wells, the social and economic significance of groundwater has dramatically increased and led to an increasing commodification of and trade in water (see Rosegrant and Binswanger 1994).

The notion that water is something whose use is not, and cannot be, exclusive to individual control and appropriation but rather is a common-pool resource therefore is quite prominent. Water, more readily than land, is perceived and legally treated as a common good over which socio-political organizations such as the state or village claim the right to regulate and distribute it. So while there usually is a close connection between water rights and land rights, water rights have a different character. The rights to appropriate water are tied to land rights, but the actual specification or 'fixing' of water rights in terms of volume or time share is dissociated from the land through processes of socio-political decision-making about water as an object of communal rights and processes of allocation. Individual rights thus remain contingent on socio-political decision-making processes. These rights therefore rarely reach the level of economic power encapsulated in ownership type of rights (see Zwarteveen 1997:1339; F. and K. von Benda-Beckmann 2000). The right to the water which has been appropriated, on the other hand, is very similar to a normal private property right.

Given the political and economic value of water, controlling water is an important element in socio-political organization. State intervention through the creation, control, and often management of technical infrastructures such as dams and irrigation systems, and through the establishment of powerful water bureaucracies, are important ways in which state structures are consolidated. ${ }^{12}$ In Indonesia, we can see quite different historical developments in different regions, largely conditioned by hydro-geographic and economic characteristics. On Java, for instance, colonial irrigation development took off at a much earlier date. It was introduced in areas for rice and sugar cultivation under the Cultivation System, or cultuurstelsel, largely located in relatively flat lands with larger streams..$^{13}$ State intervention in West Sumatra was later, and much less intense. Here the Cultivation System was used for coffee production, and rice cultivation took place under conditions of a hilly topography, a wealth of small streams, and adequate rainfall, which had fostered the

12 Forest control and management has been perceived as an important element in processes of state formation, indicating the state's 'outreach'. Control and regulation of inland water resources seems to be more important for the consolidation of state power in the territory, although there are many examples in which the development of water management and irrigation in frontier zones also considerably aids the increasing outreach of the state; Nepal's colonization and development of the Terai in the Gangetic plains is a good example (K. von Benda-Beckmann et al. 1997).

13 See Ravesteijn 1997. See also Christie, and Wolters, both in this volume. Hartveld 1996: 77 describes how in 1905 two large irrigation projects in the upper Brantas watershed were constructed for the concession area of sugar mills. 
development of a large number of small, gravity-flow and farmer-managed irrigation systems (Ambler 1989:35). Control over labour and production was much more important than control over land and water (see Ambler 1989), and the Dutch largely kept rice production on a subsistence level. While in Java detailed land records to support taxation assessments were established, in West Sumatra state taxation was based on production quotes for coffee and later on a head tax (Ambler 1989:323). This was similar on Ambon: with its cultivation of cloves before, during, and after the Cultivation System, inland water problems were even less important.

Political and economic control is even more clearly evident in relation to coastal waters and the open seas, economically important as habitat for a number of marine resources, such as fish, sea cucumbers, and shrimps. Moreover, there are economically important underwater resources, for instance gas, oil, and minerals. Here again, the multifunctionality of water creates difficulties. The question arises how the rights to access, enter, or traverse the water territory interconnect with rights to exploit the habitat for marine resources, and underwater resources. Coastal and pelagic waters are also the territory of political organization, communities, or nation-states. ${ }^{14}$ Rights concerning this territory nearly inevitably become an aspect of sovereignty rights and claims (see Byers 1991; Cullen 1997), These problems are regulated by the international law of the seas, concerned with the regulation of the territorial boundaries of states, the creation of economic interest zones, and access to underwater resources and fishing, and other rights in the global commons (Vogler 1992; Brans et al. 1997). But besides state and international law, adat may also play a role. For in adat, the territory of villages extends into the sea and to fishing grounds close to shore..$^{15}$ This means that adat rights with respect to management and use of coastal and marine resources, the uses of coral stone, sand, and fishing rights, also play a role. The best-known example of such management is probably the Moluccan institution of sasi laut. Sasi refers to an originally adat-based periodic harvest prohibition on terrestrial or marine resources that had been incorporated into colonial Dutch regulations on village government. In the 1990s, it was revitalized as a 'traditional' institution and discovered as a potentially useful traditional environmental regulation by environmentalist NGOs as well as by the Ministry of Environmental Affairs. ${ }^{16}$

Potential problems and the potential for conflicts over water increase with the spatial extension of water resources. Depending on the length of the watercourse, a stream, an irrigation system, a river, a lake, water is a trans-

14 See Osseweijer, this volume; Pannell 1997b; Peterson and Rigsby 1998.

15 Ohorella 1984; Pannell 1997b; Peterson and Rigsby 1998.

16 See the description of Ambonese land and water law by Ohorella 1994. For critical analyses of the 'reinvented' character of sasi see Zerner 1994; Pannell 1997a; Soselisa 2001. See also F. and K. von Benda-Beckmann and Brouwer 1995. 
boundary resource that flows through many communities and even nationstates. ${ }^{17}$ This necessitates agreements, rules, principles, and negotiations between the different riparian communities or even states, by communities, state governments, and in the arena of international law making. ${ }^{18}$ These discussions and rule-making activities mainly relate to international rivers and river basin management between states, but they also feed into discussions of underground aquifers (McCaffrey 1997; Neda 1998:63). ${ }^{19}$ Problems often lead to water wars (Brans et al. 1997).

\section{Political and legal pluralism}

This leads back to Sungai Tenang and political and legal pluralism. I have mentioned that rights to control, own, and allocate water and other natural resources are usually interwoven with political organization and define who has the right of socio-political control over water, who has the right to allocate water over different uses and users, and who has the right to use water. They also define obligations of the different holders of water rights. This goes for local communities as well as for nation-states. Final control over a state's water resources is one element of the internal sovereignty of states. ${ }^{20}$ In Indonesia, the right of the state to control and regulate the allocation, use, maintenance, and provision of water is firmly embedded in the constitution, the Agrarian Basic Law of 1960, and the Water Laws of 1974, and Government Regulation 22

17 Moreover, this is not confined to the actual watercourse but increasingly applies to for the river basin or catchment area.

18 International legal principles are elaborated by the International Law Association - an NGO which formulated the Helsinki Rules in 1996, the International Law Commission, a UN Commission, and the Committees of the General Assembly of the UN (see ILA 1996; Neda 1998:41; Kroes 1997; McCaffrey 1997).

19 'While the international community, as well as individual states, has an obligation to come to the assistance of those deprived individuals, it does not appear that as a practical matter human rights law presently offers much hope to the vast majority of those in grave need of access to potable water and adequate sanitation services' (McCaffrey 1997:55). These principles do not formally refer to underground aquifers that do not have a surface water component. There is, however, a growing awareness that similar principles should apply to underground waters in shared aquifers (Neda 1998:63, note 27).

20 Where states are strong (in the civil law tradition), water may be declared a public good to be wholly administered by the state, and water rights be distributed by public allocation or via licenses (see also Neda 1998:44). Irrespective of the value of a general theory like Wittfogel's (1957) about the relation between irrigation control and the emergence of powerful hierarchically organized state organizations (see Boomgaard, this volume), it is clear that the establishment of water management schemes, often around canal or tank irrigation, can be and often is an important element in processes of the formation of large and hierarchically organized political organizations. Even if the state does not actually get involved in water management, the possibility is there and can be activated, for whatever purpose. So political and economic power relations, even where not established to ensure control over water, affect relations to water. The relation between small, poor, and landlocked Nepal and huge, richer, and more powerful India is a good example. 
of 1982. In principle, everybody may use water for the necessities of their livelihood (keperluan pokok kehidupan, art. 16). Other uses require a permit from the government (art. 19). The rhetoric of the Agrarian Basic Law, that the relevant law is based on adat law as long as this does not contradict the public interest, in reality has been as spurious and misleading as it has been for land and local rights to natural resources, where adat rights have largely been disregarded to the benefit of the political and economic elite (see Fitzpatrick 1999).

We have seen in Sungai Tenang that this can change. The case illustrates that there is no clear unilineal development in the relative significance of the different bodies of law within a pluralistic legal system. While during the Suharto regime the strength and efficiency of adat law had declined, we now observe a revitalization of adat as legitimation of rights to natural resources. The new freedom and political instability under the reformasi governments of Habibie, Wahid, Megawati Soekarnoputri, and Yudhoyono have given a new impetus to this, especially since the official promulgation of the Decentralization Laws in 1999. In West Sumatra, developments are even more dynamic than in other parts of Indonesia, for here decentralization has been used to reform the organizational structure of village government. Until the early 1980s, when the 1979 Law on Local Government became effective in West Sumatra, the lowest unit of local government had been the nagari, the Minangkabau name for the former and originally pre-colonial 'village republics'. In the early 1980s, these had been replaced by the Javanese village model of desa. This meant that the nagari were split up into several smaller desa. With the decentralization law and the move towards regional autonomy, the provincial government has decided to opt for a policy of 'going back to the nagari'. Although at present it is far from clear where this process - which has different dynamics in different parts of Minangkabau - will end, and what going back to the nagari eventually will mean, this policy has already led to an official and legal rehabilitation of adat and adat law. ${ }^{21}$ Provincial Regulation 9 of 2000, through which the 'back to the nagari' policy is structured, now explicitly mentions in section 7(d) as 'property and wealth of the nagari' 'the land, forest, rivers, ponds, lakes and sea' that are ulayat of the nagari. This not only concerns rights to resources, but also the principles according to which representative village councils are to be formed (see F. and K. von Benda-Beckmann 2001a,b, 2004).

In the view of the government, this recognition of adat may be largely rhetorical. ${ }^{22}$ But the people take it seriously. And the people, as the example

21 These notions are replicated in the new regulations at district and village levels. The same formulations had already been used in the regulation of 1983, which recognized and legally established the Adat Village Council (Kerapatan Adat Nagari) in addition to the desa (F. and K. von Benda-Beckmann 2001b).

22 Peraturan Menteri Negara Agraria/Kepala Badan Pertanahan Nasional Nomor 5 tahun 1999 on the right of avail, the beschikkingsrecht, makes clear that village control over natural resources excludes those resources that had been converted into state rights earlier. 
of Sungai Tenang and also of West Sumatran legal politics generally shows, are not necessarily old-fashioned traditional leaders pursuing nostalgic goals. They are largely modern, well-educated people, and their concern is not so much adat per se but the economic resources and political power that can be legitimated by reference to adat. The Association of Adat Councils, LKAAM, has become a strong lobby for a wider recognition of adat. Until shortly before the last elections still a part of GOLKAR and generally regarded as an instrument to contain adat aspirations, LKAAM has become the strongest adat voice, very much to the irritation of the provincial and regency governments. The LKAAM leadership does not consist of simple traditionalists; they are mainly academically trained; they hold jobs at the university or are retired government officials (F. and K. von Benda-Beckmann 2001b).

The example also tells us about the different ways in which notions of adat rights are restated in a rather 'pure' form and also become enmeshed and partly incorporated in government law. In both cases one could say that we are dealing here with reinventions of traditional legal concepts which no longer reflect political and economic realities. But this is beside the point. Adat restated in a supposedly old, traditionalist version, is a good bargaining chip in negotiations over resource rights, as the example shows. This is not confined to West Sumatra, although the return to the nagari policy gives a special character to the development there (see Li 2000; Acciaioli 2001).

Increasingly, such combinations of mobilizing adat rights in their 'pure form' and merging them with government law are no longer confined to state law and adat. A variety of new international or transnational actors have entered the scene during the last two decades, actors such as the World Bank, Asian Development Bank, International Water Management Institute (IWMI), and other donor agencies. They advise governments and also get directly involved in the planning and execution of water management projects, with high ambitions such as making water supply and distribution more efficient, equitable, and sustainable. Wholly new policy and legal discourses debate the value of community-based water resources management but also of tradable water rights. International donor agencies emphasize the need for bottom-up management of natural resources and the need for policy-makers to draw lessons from traditional legal forms of resource management (see Neda 1998:44).23 Local actors in West Sumatra as elsewhere ${ }^{24}$ also use this

23 Pinstrup -Andersen (2000:15): “Water rights are fundamental. Currently, irrigation accounts for over $70 \%$ of water withdrawals world-wide, and even more in many developing countries. The question of how the customary rights of existing water users are acknowledged, and whether new allocation patterns are imposed or negotiated with users, will have a major bearing on rural livelihoods as well as food security." It has become common to say that "legal reform may have some important lessons to learn from traditional legal systems" (Howsam 1996:378).

24 A well-known instance of the resurgence of traditional water resources management is the Moluccan institution for harvesting of marine resources, sasi laut, that has been discovered by a 
development policy language of bottom-up development to support their claims. So traditional legal elements - however well or poorly understood - are strengthened and incorporated into global and transnational legal and policy discourses. The international legal dimension has further gained in importance since the right to water, at least to clean drinking water, is increasingly interpreted as a human right, although, as the Water Forum in The Hague has taught us, not everyone agrees

This new legal and political context will also influence future developments in Indonesia. At present, plans for a comprehensive reform ${ }^{25}$ are being made in cooperation with the Word Bank and World Bank consultants. Solving, or at least minimizing, conflicts between the different economic and political interests, and the different legal orders invoked to legitimate those interests, will be one of the major problems (Hardiyanto 1997). The current policy of decentralization offers great opportunities and at the same time creates additional problems. The tug of war over control over land between the centre's Badan Pertanahan Nasional (BPN, National Land Administration Board), and on the other hand the districts and villages as well as the provinces is still going on, and it will colour the way and the extent to which the reform of the water sector will be carried out. The Land Administration should be decentralized, but some powers at national level do not want this.

\section{A final outlook}

It is likely that problems related to water and struggles over water rights will not only continue but increase. Although much public attention is given to these problems, there are few indications of improvement in the extent of exploitation and distribution of water. The question whether water, and especially groundwater, can be left to unrestrained individual appropriation, through market mechanisms or otherwise, has not been answered. The declaration of the right to water as a human right has been important, but mainly only symbolically. Especially the propagation of water as an 'economic' rather than a social good in neoliberal resource policies has led to grave concerns about the availability of water for the poor and to the fear that sufficient water may become a life-giving force reserved for the economically privileged. ${ }^{26}$

number of national and transnational NGOs. See Zerner 1994; Pannell 1997; Soselisa 2001; F. and K. von Benda-Beckmann and Brouwer 1995.

25 First steps were the Law on Water 11 of 1974 . This was adapted in 1982 by Government Regulation 22 of 1982. Government Regulation 23 of 1982 detailed this further for irrigation.

26 See Ahmed, Dixit and Nady 1999; Shiva 1999; Shah 1998; Editorial 1999; Middleton 1994. 


\section{Bibliography}

Acciaioli, Greg

2000

'The re-emergence of customary claims to land among the To Lindu of Central Sulawesi; The revitalisation of Adat in the era of Reformasi in Indonesia.' Paper Annual Conference of the Australian Anthropological Aditjondro, George Society, The University of Western Australia, Perth ,19-23 September.

1998

'Large dam victims and their defenders; The emergence of an anti-dam movement in Indonesia', in: P. Hirsch and C. Warren (eds), The politics of environment in Asia; Resources and resistance, pp. 29-54. London: Routledge.

Ahmed, Imtiaz, Ajaya Dixit and Ashis Nady

1999 'Water, power and people; A South Asian manifesto on the politics and knowledge of water', Water Nepal 7:113-21.

Ambler, John

1989

Adat and aid; Management of small-scale irrigation in West Sumatra, Indonesia. PhD thesis, Cornell University, Ithaca, NY.

Baehr, Peter and Koo van der Wal

1990 'Introduction item: Human rights as individual and as collective rights', in: Jan Berting et al. (eds), Human rights in a pluralist world; Individuals and collectivities, pp. 33-7. Westport/London: Meckler.

Benda-Beckmann, Franz von

1979 Property in social continuity; Continuity and change in the maintenance of property relationships through time in Minangkabau, West Sumatra. The Hague: Nijhoff. [KITLV, Verhandelingen 86.]

2002 'Who's afraid of legal pluralism?', Journal of Legal Pluralism 47:37-82.

Benda-Beckmann, Franz von and Keebet von Benda-Beckmann

2000 'Gender and the multiple contingencies of water rights in Nepal', in:

Rajendra Pradhan, Franz von Benda-Beckmann and Keebet von BendaBeckmann (eds), Water, land and law; Changing rights to land and water in Nepal, pp. 17-38. Kathmandu: Freedeal, Wageningen: WAU, Rotterdam: EUR.

2001a 'Actualising history for binding the future; Decentralisation in Minangkabau', in: Paul Hebinck and Gerard Verschoor (eds), Resonances and dissonances in development; Actors, networks and cultural repertoires, pp. 33-47. Assen: Van Gorcum.

2001b Recreating the nagari; Decentralisation in West Sumatra. Halle/Saale: Max Planck Institute for Social Anthropology. [Working Paper 31.]

2003 'Water, human rights and legal pluralism', in: Water, human rights and governance, pp. 63-76. Kathmandu: Format Printing Press. [Special Issue Water Nepal, vol. 9/10.]

2004 Struggles over communal property rights and law in Minangkabau, West Sumatra. Halle: Max Planck Institute for Social Anthropology. [Working Paper 64.]

Benda-Beckmann, Franz von, Keebet von Benda-Beckmann and Arie Brouwer 1995 'Changing "indigenous environmental law" in the Central Moluccas; Communal regulation and privatization of Sasi', Ekonesia 2:1-38. 
Benda-Beckmann, Franz von, Keebet von Benda-Beckmann and H. Joep L. Spiertz 1997 'Local law and customary practices in the study of water rights', in Rajendra Pradhan, Franz von Benda-Beckmann, Keebet von BendaBeckmann, H. Joep L. Spiertz, Shantam Shantam Kadka and K. A. Haq (eds), Water rights, conflict and policy, pp. 221-42. Colombo: IIMI.

Benda-Beckmann, Keebet von, H. Joep L. Spiertz and Franz von Benda-Beckmann 1997

'Disputing water rights; Scarcity of water in Nepal hill irrigation', in: Edward H.P. Brans, Esther J. de Haan, André Nolkaemper and Jan Rinzema (eds), The scarcity of water, pp. 224-42. London/Den Haag/ Boston: Kluwer International.

Boelens, Rutgerd and Gloria Dávila (eds)

1998 Searching for equity: Conceptions of justice and equity in peasant irrigation. Assen: Van Gorcum.

Brans, Edward H.P., Esther J. de Haan, André Nolkaemper and Jan Rinzema (eds) 1997 The scarcity of water. London/Den Haag/Boston: Kluwer International. Bruns, Bryan R. and Ruth S. Meinzen-Dick (eds)

$2000 \quad$ Negotiating water rights. New Delhi: Vistaar Publications.

Burgers, J. Herman

1990 'The function of human rights as individual and collective rights', in: J. Berting et al. (eds), Human rights in a pluralist world; Individuals and collectivities, pp. 63-74. Westport/London: Meckler.

Byers, Bruce

1991

'Ecoregions, state sovereignty and conflict', Bulletin of Peace Proposals 22-1:65-76.

Cullen, Richard

1997 'Natural resources in the offshore; The Australian position after Mabo's case', in: Franz von Benda-Beckmann, Keebet von Benda-Beckmann en André J. Hoekema (eds), Natural resources, environment and legal pluralism, pp. 158-74. The Hague: Nijhoff. [Special issue Law and Anthropology 9.]

Derman, Bill

1998 'Balancing the waters; Development and hydropolitics in contemporary Zimbabwe', in: John M. Donahue and Barbara R. Johnston (eds), Water, culture and power; Local struggles in a global context, pp. 73-93. Washington, DC: Island Press.

Donahue, John M. and Barbara R. Johnston (eds)

1998 Water, culture and power; Local struggles in a global context. Washington, DC: Island Press.

Donnelly, Jack

1990 'Human rights, individual rights and collective rights', in: Jan Berting et al. (eds), Human rights in a pluralist world; Individuals and collectivities, Falkenmark, Malin pp. 39-62. Westport/London: Meckler.

'Water scarcity - challenges for the future', in: Edward H.P. Brans, Esther J. de Haan, André Nolkaemper and Jan Rinzema (eds), The scarcity of water, pp. 21-39. London/Den Haag/Boston: Kluwer International. 
Fitzpatrick, Daniel

1999 'Beyond dualism; Land acquisition and law in Indonesia', in: Timothy Lindsey (ed.), Indonesia: Law and society, pp. 74-96. Sydney: Federation Press.

Gleick, Peter et al. (eds)

$1993 \quad$ Water in crisis; A guide to the world's fresh water resources. Oxford: Oxford University Press.

Global water worries

1999 'Global water worries and local complexities; Editorial', Water Nepal 7:1-7.

Hardiyanto, Andik

1997 'Pembaruan agraria di sektor perairan; Perlu dan mendesak', in: Dianto Bachriadi, Erpan Faryadi dan Bonnie Setiawan (eds), Reformasi agraria, pp. 169-79. Jakarta: Konsorsium Pembaruan Agraria, Jakarta: Lembaga Penerbit Fakultas Ekonomi, Universitas Indonesia.

Hammoudi, Abdullah

1984 'Substance and relation; Water rights and water distribution in the Dra valley', in: Ann Elizabeth Mayer (ed.), Property structure and law in the modern Middle East, pp. 169-79. Albany: State University of New York Press.

Hartveld, Aart J.

$1966 \quad$ Raising cane; Linkages, organizations and negotiations in Malang's sugar industry, East Java. PhD thesis Wageningen University.

Howsam, Peter

1996 'Water laws, water rights and water policy', in: Peter Howsam and Richard Carter (eds), Water policy; Allocation and management in practice, pp. 371-8. London: Spon.

Hunt, Eva V. and Robert C. Hunt

1974 'Irrigation, conflict and politics; A Mexican case', in: Theodore E. Downing and McGuire Gibson (eds), Irrigation's impact on society, pp. 129-57. Tucson: University of Arizona Press.

ILA

1996 Helsinki rules on the uses of the waters of international rivers. Adopted by the International Law Association at the 52nd Conference, Helsinki, 20th August 1966. London: International Law Association.

Johnston, Barbara R. and John M. Donahue

1998 'Introduction', in: John M Donahue and Barbara R. Johnston (eds), Water, culture and power; Local struggles in a global context, pp. 1-5. Washington, DC: Island Press.

Kroes, Matjon

1997 'The protection of international watercourses as sources of fresh water in the interest of future generations', in: E.H.P. Brans, E.J. de Haan, A. Nolkaemper and J. Rinzema (eds), The scarcity of water, pp. 80-99. London/Den Haag/Boston: Kluwer International.

Kurnia, Ganjar, Teten W. Avianto and Bryan R. Bruns

2000 'Farmers, factories and the dynamics of water allocation in West Java', in Bryan R. Bruns and Ruth S. Meinzen-Dick (eds), Negotiating water rights, pp. 292-314. New Delhi: Vistaar Publications. 
Li, Tania Murray

2001 'Masyarakat adat, difference, and the limits of recognition in Indonesia's forest zone', Modern Asian Studies 35-3:645-76.

McCaffrey, Stephen

1997 'Water scarcity; Institutional and legal responses', in: Edward H.P. Brans, Esther J. de Haan, André Nolkaemper and Jan Rinzema (eds), The scarcity of water, pp. 43-58. London/Den Haag/Boston: Kluwer International.

Management

1998

The management of shared river basins; Experiences from SADC and EU. The Hague: Ministry of Foreign Affairs Neda. [Focus on Development 8.]

Middleton, Neil et al. (eds)

1994

The tears of the crocodile; From Rio to reality in the developing world. Boulder: Westview Press.

Nader, Laura

1996

'Civilizations and its negotiations', in: Pat Caplan (ed.), Understanding disputes; The politics of argument, pp. 39-63. Oxford/ Providence, RI: Berg.

Ohorella, Mohammad Galna

$1994 \quad H u k u m$ adat mengenai tanah dan air di pulau Ambon dan sumbangannya terhadap pembangunan hukum agraria nasional. $\mathrm{PhD}$ thesis Universitas Hasanuddin, Ujung Pandang.

Pandecten van het adatrecht

1914 Pandecten van het adatrecht; I. Beschikkingsrecht over grond en water. Amsterdam: De Bussy.

Pannell, Sandra

'Managing the discourse of resource management; The case of Sasi from "Southeast" Maluku, Indonesia', Oceania 67:289-307.

1997 'From the poetics of place to the politics of space; Redefining cultural landscapes on Damar, Maluku Tenggara', in: Jim Fox (ed.), The poetic power of place; Comparative perspectives on Austronesian ideas of locality, pp. 163-74. Canberra: Research School of Pacific and Asian Studies, Australian National University.

Pannell, Sandra and Franz von Benda-Beckmann

1998 'Introduction', in: Sandra Pannell and Franz von Benda-Beckmann (eds), Old world places, new world problems; Exploring issues of resource management in eastern Indonesia, pp. 1-33. Canberra: Centre for Resource and Environmental Studies, Australian National University.

Peterson, Nicolas and Bruce Rigsby (eds)

1998 Customary marine tenure in Australia. Sydney: University of Sydney. [Oceania Monographs 48.]

Pinstrup-Andersen, Per

2000 'Foreword', in: Bryan R. Bruns and Ruth S. Meinzen-Dick (eds), Negotiating water rights, pp. 15-6. New Delhi: Vistaar Publications.

Postel, Sandra L.

1992 Last oasis; Facing water scarcity. New York: Norton. 
Postel, Sandra et al.

1996 'Human appropriation of renewable fresh water', Science 271:785-88.

Pradhan, Rajendra, Franz von Benda-Beckmann and

Keebet von Benda-Beckmann (eds)

2000 Water, land and law; Changing rights to land and water in Nepal. Kathmandu: Freedeal, Wageningen: WAU, Rotterdam: EUR.

Ravesteijn, Wim

1997 De zegenrijke heeren der wateren; Irrigatie en staat op Java, 1832-1942. PhD thesis Delft University.

Rosegrant, Mark W. and Hans P. Binswanger

1994

'Markets in tradable water rights; Potential for efficiency gains in developing country water resource allocation', World Development 22:1613-25.

Roth, Dik, Rutgerd Boelens and Margreet Zwarteveen (eds)

2005 Liquid relations; Contested water rights and legal complexity. New Brunswick, NJ/London: Rutgers University Press.

Sadeque, Syed Zahir

2000 'Nature's bounty or scarce commodity; Competition and consensus over groundwater use in rural Bangladesh', in: B.R. Bruns and R.S. Meinzen-Dick (eds), Negotiating water rights, pp. 269-91. New Delhi: Vistaar Publications.

Saeijs, Henk L.F. and M.J. van Berkel

1997

'The global water crisis; The major issue of the twenty-first century, a growing and explosive problem', in: Edward H.P. Brans, Esther J. de Haan, André Nolkaemper and Jan Rinzema (eds), The scarcity of water, Sakai, Minako pp. 3-20. London/Den Haag/Boston: Kluwer International.

2003

'The privatisation of Padang Cement; Regional identity and economic hegemony in the new era of decentralisation', in: Edward Aspinall and Greg Fealy (eds), Local power and politics in Indonesia; Decentralisation and democratisation, pp. 148-163. Singapore: Institute of Southeast Asian Studies.

Shah, Tushar

1998 'Water against poverty; Livelihood-oriented water resources management', Water Nepal 6:117-43.

Shiva, Vandana

1999 'Diversity and democracy; Resisting the global economy', Global Dialogue 1:19-30.

Simbolon, Indira Juditka

$1998 \quad$ Peasant women and access to land; Customary law, state law and genderbased ideology; The case of the Toba-Batak (North Sumatra). PhD thesis Soselisa, Hermien Wageningen University.

2001

'Sasi Laut di Maluku; Pemilikan komunal dan hak-hak komunitas dalam manajemen sumber daya kelautan', in: F. von Benda-Beckmann, K. von Benda-Beckmann and J. Koning (eds), Sumber daya alam dan jaminan sosial, pp. 227-60. Yogyakarta: Pustaka Pelajar. 
United Nations

1997 Convention on the Law of the non-navigational uses of international water courses. New York: United Nations.

UNCED

1992

Rio declaration on environment and development, Rio de Janeiro. New York: United Nations.

$\mathrm{UN} / \mathrm{ECE}$

1992

Convention on the protection and use of transboundary watercourses and international lakes; Done at Helsinki on 17 March 1992. New York: United Nations.

Vogler, John

1992

'Regimes and the global commons; space, atmosphere and oceans', in: Anthony G. McGrew and Paul G. Lewis et al. (eds), Global politics; Globalization and the nation-state', pp. 118-37. Cambridge: Polity Press.

Vollenhoven, Cornelis van

$1918 \quad$ Het adatrecht van Nederlandsch-Indië. Leiden: Brill.

Wiber, Melanie G.

1991 'Levels of property rights, levels of law; A case study from the northern

Willinck, G.D. Philippines', Man 26:469-92.

$1909 \quad H e t$ rechtsleven bij de Minangkabausche Maleiers. Leiden: Brill.

Wittfogel, Karl A.

1957 Oriental despotism; A comparative study of total power. New Haven: Yale University Press.

Zerner, Charles

1994 'Through a green lens; The construction of customary environmental law and community in Indonesia's Maluku islands', Law and Society Review 28:1079-1122.

Zwarteveen, Margreet Z.

1997 'Water: from basic need to commodity; A discussion on gender and water rights in the context of irrigation', World Development 25- 8:1335-49. 